\title{
To fast or not to fast during the month of Ramadan? A comprehensive survey on religious beliefs and practices among Moroccan diabetic patients
}

This article was published in the following Dove Press journal:

Diabetes, Metabolic Syndrome and Obesity:Targets and Therapy

\author{
Eisa Al-Balhan ${ }^{1, *}$ \\ Hicham Khabbache ${ }^{2, *}$ \\ Abdelhadi Laaziz ${ }^{2}$ \\ Ali Watfa ${ }^{3}$ \\ Abdelkader Mhamdi ${ }^{4}$ \\ Giovanni Del Puente 5 \\ Nicola Luigi Bragazzi ${ }^{5-8}$ \\ 'Department of Educational \\ Psychology, College of Education, \\ Kuwait University, Kuwait City, \\ Kuwait; ${ }^{2}$ Faculty of Literature \\ and Humanistic Studies, Sais, Sidi \\ Mohamed Ben Abdellah University, \\ Fez, Morocco; ${ }^{3}$ Faculty of Education, \\ Kuwait University, Kuwait City, \\ Kuwait; ${ }^{4}$ Department of Sociology, \\ Sais, Sidi Mohamed Ben Abdellah \\ University, Fez, Morocco; ${ }^{5}$ DINOGMI, \\ Department of Neuroscience, \\ Rehabilitation, Ophthalmology, \\ Genetics, Maternal and Child Health, \\ Section of Psychiatry, University of \\ Genoa, Genoa, Italy; ' $U N E S C O$ Chair \\ "Health Anthropology, Biosphere \\ and Healing Systems", University \\ of Genoa, Genoa, Italy; ${ }^{7}$ Gestalt \\ Study Center (CSTG), Milano, Italy; \\ ${ }^{8}$ Department of Health Sciences \\ (DISSAL), Postgraduate School of \\ Public Health, University of Genoa, \\ Genoa, Italy \\ *These authors contributed equally to \\ this work
}

Correspondence: Nicola Luigi Bragazzi Department of Health Sciences (DISSAL), Postgraduate School of Public Health, University of Genoa (DISSAL), Via Antonio Pastore I, Genoa 16132, Italy Email robertobragazzi@gmail.com
Background: Diabetes represents a major public health concern. According to the International Diabetes Federation, about $8 \%-9 \%$ of the population have diabetes, and rates are even higher among Muslim communities. Despite the risks, about half (43\%) with type 1 diabetes and most ( $86 \%)$ of those with type 2 diabetes fast during Ramadan. However, there is a dearth of information concerning the determinants that drive diabetic people to fast. Therefore, the present study was designed to fill this gap in knowledge.

Materials and methods: A sample of 201 subjects volunteered to take part in this study. Mean age was 45.39 \pm 15.74 years. Most participants were female, married and had received at least primary education. They fasted for $22.98 \pm 8.53$ days.

Results: For the overall questionnaire, the Cronbach's alpha coefficient was found to be excellent $(\alpha=0.910)$. The coefficient was good, yielding a value of 0.879 , for the items concerning Ramadan fasting beliefs and practices, whereas the subscale for religious beliefs and practices obtained a score of 0.847 . At the univariate analysis, patients with complicated diabetes $(n=66$, $32.8 \%$ of the sample) fasted for $20.77 \pm 9.21$ days vs subjects with diabetes ( $n=135,67.2 \%$ of the interviewees), who fasted for $24.05 \pm 7.99$ days. The difference was statistically significant $(P=0.014)$. The multivariate analysis indicated that religious beliefs and practices influenced the number of fasting days in a statistically significant way, after adjusting for confounders (beta coefficient $=-0.199, t=-2.917, P=0.004)$. Another variable that impacted on the number of fasting days was the presence of complications (beta coefficient $=-0.194, t=-2.775, P=0.006$ ). Conclusion: Our results warrant further studies in the field.

Keywords: diabetes, Ramadan fasting, religious beliefs and practices, survey

\section{Introduction}

Diabetes represents a major public health concern. According to the International Diabetes Federation, about $8 \%-9 \%$ of the population suffer from diabetes, ${ }^{1,2}$ and rates are even higher among Muslim communities. For instance, the North African region as a whole has the second highest comparative prevalence of diabetes $(10.7 \%)$ vs a rate of $6.7 \%$ in Europe and a rate of only $4.5 \%$ in Africa. ${ }^{3}$ Furthermore, six Muslim countries, like Kuwait (21.1\%), Lebanon (20.2\%), Qatar (20.2\%), Saudi Arabia (20.0\%), Bahrain (19.9\%) and United Arabian Emirates (19.2\%), are among the top 10 countries in terms of diabetes-related burden. ${ }^{3}$ Other Muslim countries, such as Egypt, Bangladesh, and Indonesia, have similar high rates of diabetes prevalence. $^{4}$ 
Despite the risks, about half (43\%) with type 1 diabetes and most (86\%) of those with type 2 diabetes are eager to fast during Ramadan. Approximately $50 \%$ of the whole population of diabetic patients did not change their lifestyle during Ramadan, whereas the other half of patients tend to decrease physical activity, sleep duration, and food, sugar, and fluid intake. ${ }^{5}$

Ramadan fasting represents one of the five pillars of the Islam creed. Even though patients are exempted from observing this religious duty, they may be eager to share this particular moment of the year with their family and peers. ${ }^{6,7}$ However, other factors can influence the decision to fast, such as guilty feelings, the sensation of shame, stigma, familial and societal pressure. ${ }^{8}$

Fasting during Ramadan has been uniformly discouraged by the medical profession and by the scientific community for patients suffering from diabetes. The large, multi-country, population-based epidemiological study "Epidemiology of Diabetes and Ramadan 1422/2001" (EPIDIAR) conducted in 13 Islamic countries on a sample of 12,243 diabetics $(1,070$ with type 1 diabetes and 11,173 with type 2 diabetes) who fasted during Ramadan showed a high rate of acute complications, such as hypoglycemia or hyperglycemia, diabetic ketoacidosis, dehydration, and thrombosis, among others. ${ }^{5}$

These findings have been replicated by other high-quality epidemiological surveys, such as the CREED study. ${ }^{6}$

However, there is a dearth of information concerning the determinants that drive diabetic people to fast during the month of Ramadan. Therefore, given the importance of this topic, the present study was designed to fill this gap in knowledge.

\section{Materials and methods}

\section{Instrument}

For the present survey, an ad hoc questionnaire was devised based on an expert panel, literature review, and focus groups with a small sample of 20-30 Moroccan diabetics among whom the questionnaire administration was pilot tested. The items were checked for readability and clarity. The final version comprised 40 items, subdivided into two subscales (one concerning Ramadan fasting beliefs and practices and another related to religious beliefs and practices).

A brief section of the questionnaire aimed at collecting basic sociodemographic information, namely, gender, age, occupation (working/not working), family status (married, unmarried), educational level (primary, secondary, or tertiary education), and eventual complications of the diabetes/ comorbidities.

\section{Statistical analysis}

Before proceeding with data handling and processing, all figures were visually inspected for potential outliers. Normality of data was verified by conducting the D'Agostino-Pearson omnibus test. Based on the normal distribution, parametric or nonparametric tests were chosen and performed (namely, Student's $t$-test, ANOVA, Kruskall-Wallis test, the MannWhitney $U$ test, and chi-squared test).

Reliability was quantitatively assessed by computing the Cronbach's alpha coefficient. In order to properly interpret the magnitude of the alpha coefficient, the following rule of thumb was used: the reliability/consistency was deemed excellent if the coefficient was greater than 0.9 , good with the coefficient in the range $0.8-0.9$, acceptable in the range $0.7-0.8$, questionable or adequate in the range $0.6-0.7$, poor in the range $0.5-0.6$, and unacceptable if the coefficient was less than 0.5 .

Pearson's coefficient ( $r$ coefficient) was calculated. The strength of correlation was measured using the rule of thumb described by Hinkle et al: ${ }^{7}$ negligible correlation with $r$ coefficient in the range 0.00-0.30, low correlation with $r$ in the range $0.30-0.50$, moderate correlation with $r$ in the range $0.50-0.70$, high correlation with $r$ in the range $0.70-0.90$, and very high correlation with $r$ in the range $0.90-1.00$.

All statistical analyses were carried out with the commercial software SPSS for Windows, version 24 (IBM Corporation, Armonk, NY, USA).

Figures with $P$-values less than 0.05 were considered to be statistically significant.

\section{Ethical clearance}

The study protocol of the present investigation was reviewed and approved by the Ethical Committee of the Faculty of Literature and Humanistic Studies, Sais, Sidi Mohamed Ben Abdellah University, Fez, Morocco. All the procedures followed in the current article adhere to the 1964 Helsinki statement and its subsequent amendments. Each participant signed a written consent form. In case the subject was under the legal age for the consent, parental/legal guardian informed consent was sought and obtained. Participation was on a voluntary basis.

\section{Results}

A sample of 201 subjects suffering from type 2 diabetes volunteered to take part in this study. Mean age was $45.39 \pm 15.74$ years (range from 14 to 85 years, median 45 years). Most participants were female $(n=118,58.7 \%$ of the sample), 
Table I Characteristics of the recruited sample

\begin{tabular}{|l|l|}
\hline Parameter & Value \\
\hline Age (years) & $45.39 \pm 15.74$ \\
Gender (number, \%) & $83(41.3 \%)$ \\
Male & $118(58.7 \%)$ \\
Female & \\
Family status (number, \%) & $138(68.7 \%)$ \\
$\quad$ Married & $63(31.3 \%)$ \\
Not married & \\
Educational level (number, \%) & $95(47.3 \%)$ \\
Primary & $75(37.3 \%)$ \\
Secondary & $31(15.4 \%)$ \\
Tertiary & \\
Type of disease (number, \%) & $135(67.2 \%)$ \\
Diabetes & $12(6.0 \%)$ \\
Diabetes with cardiovascular complications & $48(23.9 \%)$ \\
Diabetes and hypertension & $6(3.0 \%)$ \\
Diabetes and other chronic disorders & \\
Occupation (number, \%) & $59(29.4 \%)$ \\
Not working/unemployed & $142(70.6 \%)$ \\
Working & $22.98 \pm 8.53$ \\
Number of fasting days & \\
\hline
\end{tabular}

married ( $\mathrm{n}=138,68.7 \%)$, and had received at least primary education ( $\mathrm{n}=95,47.3 \%)$. They fasted for $22.98 \pm 8.53$ days (range from 5 to 30 days, median 30 days). Further details are shown in Table 1.

Scores obtained for each item (reported in Table 2) are shown in Table 3. Skewness and kurtosis values were deemed acceptable as well as the sampling adequacy.

For the overall questionnaire, the Cronbach's alpha coefficient was found to be excellent $(\alpha=0.910)$. The coefficient was good, yielding a value of 0.879 for the items concerning Ramadan fasting beliefs and practices, whereas the subscale for religious beliefs and practices obtained a score of 0.847 . Ramadan subscale can be further subdivided into two sections: one containing positive items (namely, items 1, 5 7,8, and 13), with $\alpha=0.769$, and one containing negative items, with $\alpha=0.836$ (comprising the remaining items, which are to be reverse scored). Further details are shown in Table 4 . The correlation between the two subscales was found to be moderate, with a coefficient of $0.580(P<0.001)$.

Our questionnaire explores different dimensions such as the perceived risks related to fasting, the sense of guilty and embarrassment of not fasting, and the complex interplay between medical doctors and spiritual guides ("shuyukh", "fuqahā", "a'immah", and other religious leaders).

Concerning the perceived risk, as expressed by the items 12 ("I accept to increase the symptoms of the disease during fasting on the month of Ramadan"), 41 (20.4\%) strongly disagreed, 37 (18.4\%) disagreed, 67 (33.3\%) were neutral, 41 (20.4\%) agreed, and 15 (7.5\%) strongly agreed. Similarly, for the item 10 ("I am afraid that I will be at risk of dying during the Ramadan fasting"), 23 (11.4\%) strongly disagreed, 50 (24.9\%) disagreed, 66 (32.8\%) were neutral, 40 (19.9\%) agreed, and 22 (10.9\%) strongly agreed. For the item 11 ("I am at risk of complications or of death because of fasting as I do not adhere to the doctor's advice"), 45 (22.4\%) and $40(19.9 \%)$ strongly disagreed and disagreed, respectively, whereas 53 (26.4\%) were neutral, 45 (22.4\%) agreed, and $18(9.0 \%)$ strongly agreed with the statement.

Some of the questions of the questionnaire concerned specifically the relationship with Western medicine and drugs: for instance, concerning the item 28 ("I think that my life and my health are entirely in God's hands and are not influenced whether I take or not drugs"), only $13(6.5 \%)$ subjects strongly disagreed. Other $12(6.0 \%)$ individuals disagreed, whereas 57 (28.4\%) were neutral, 53 (26.4\%) agreed, and $65(32.3 \%)$ strongly agreed (one answer was not given). Similar patterns were obtained for the item 27 ("I think that God is the healer alone and there is no need for medicine"): 8 (4.0\%) and 19 (9.5\%) strongly disagreed and disagreed, respectively. Although 54 (26.9\%) were neutral, 70 (34.8\%) and $50(24.9 \%)$ agreed and strongly agreed, respectively. Another interesting question was raised by item 35 ("I can only get sick or worse with medication"): $20(10.0 \%)$ strongly disagreed, 22 (10.9\%) disagreed, 60 (30.0\%) were neutral, 70 (34.8\%) agreed, and 29 (14.4\%) strongly agreed. Similarly, for item 30 ("I believe that the righteous are engaged in reciting the "Qur'an" and doing supplication, without having the need of taking medication"), 16 (8.0\%) strongly disagreed, whereas 11 (5.5\%) disagreed, 62 (30.8\%) were neutral, 73 (36.3\%) agreed, and 39 (19.4\%) strongly agreed.

For the univariate analysis, patients with complicated diabetes ( $\mathrm{n}=66,32.8 \%$ of the sample) fasted for $20.77 \pm 9.21$ days vs subjects with diabetes $(\mathrm{n}=135,67.2 \%$ of the interviewees), who fasted for $24.05 \pm 7.99$ days. The difference was statistically significant $(P=0.014)$. There was no impact of family status: married and not married individuals fasted for $22.92 \pm 8.59$ and $23.10 \pm 8.44$ days, respectively $(P=0.913)$. Similarly, the influence of educational level could not be detected: subjects with tertiary education fasted for $24.19 \pm 7.08$ days, slightly longer than people with primary or secondary education $(22.75 \pm 8.76$ days; $P=0.505)$. Furthermore, there were no differences in terms of gender: male and female diabetic patients fasted for $23.65 \pm 7.84$ and $22.50 \pm 8.98$ days, respectively $(P=0.488)$.

The correlation between the number of fasting days and age was found to be negligible but significant, yielding a value of -0.16 ( $P=0.024)$. Similarly, correlations between the number of fasting days and the Ramadan fasting, religious 
Table 2 The items of the ad hoc questionnaire, designed and developed to investigate Ramadan fasting as well as other religious beliefs and practices

\begin{tabular}{|c|c|}
\hline Number & Item \\
\hline \multicolumn{2}{|c|}{ Ramadan fasting beliefs and practice subscale } \\
\hline I & I think that Ramadan fasting is a cure for my illness, even though my doctor and my spiritual guide have advised me not to fast \\
\hline 2 & I am embarrassed when I have to break the fast of Ramadan in front of people. \\
\hline 3 & I do not openly break the fast of Ramadan. \\
\hline 4 & I am afraid that I will have problems with others if I do not fast during the month of Ramadan. \\
\hline 5 & I consider fasting in Ramadan, despite my illness, increases closeness to God. \\
\hline 6 & I do not think that the first obligation to fast is to carefully listen to doctor's advice. \\
\hline 7 & I feel that I can fast because my illness and/or my age have not yet reached an advanced stage. \\
\hline 8 & $\begin{array}{l}\text { I think that whoever dies while fasting, even though it would not be permissible to fast for him/her (eg, due to sickness), is in } \\
\text { the order of the martyrs with God. }\end{array}$ \\
\hline 9 & I think that I can openly break the Ramadan fast only with my family and people with whom I have an intimate relationship. \\
\hline 10 & I am afraid that I will be at risk of dying during the Ramadan fasting. \\
\hline 11 & I am at risk of complications or of death because of fasting as I do not adhere to the doctor's advice. \\
\hline 12 & I accept to increase the symptoms of the disease during fasting in the month of Ramadan. \\
\hline 13 & I believe that preserving religion is more important than self-preservation. \\
\hline 14 & I think the doctor's advice not to fast is not binding. \\
\hline 15 & I consider the position of medicine which allows me not to fast contrary to the Shariah (Islamic law). \\
\hline 16 & $\begin{array}{l}\text { I would feel guilty if I would follow the shuyukh, fuqahā, a'immah (spiritual guides/leaders)'s advice, who have permitted me not } \\
\text { to fast. }\end{array}$ \\
\hline 17 & I feel bad when I break the fast. \\
\hline 18 & When I break the fast, I feel that others are looking at me with contempt. \\
\hline 19 & $\begin{array}{l}\text { I think that the permission of the shuyukh, fuqahā, a'immah (spiritual guides/leaders) for me not to fast during the month of } \\
\text { Ramadan is not obligatory. }\end{array}$ \\
\hline 20 & I do not accept that a person breaks the fast in front of me while I am still fasting. \\
\hline \multicolumn{2}{|c|}{ Religious beliefs and practice subscales } \\
\hline 21 & I try to pray all my prayers in the mosque. \\
\hline 22 & I am committed to praising and making supplications, after every prayer. \\
\hline 23 & I am committed to reading the Qur'an on a daily basis. \\
\hline 24 & I abide by honesty and integrity in dealing with all people. \\
\hline 25 & I consider that Islam is the true religion that should be observed in all its teachings and precepts. \\
\hline 26 & I consider my sickness to be from God in order to strengthen my faith. \\
\hline 27 & I think that God is the healer alone and there is no need for medicine. \\
\hline 28 & I think that my life and my health are entirely in God's hands and are not influenced by whether or not I take drugs. \\
\hline 29 & I believe that the Qur'an will heal all physical diseases. \\
\hline 30 & $\begin{array}{l}\text { I believe that the righteous are engaged in reciting the Qur'an and doing supplication, without having the need for taking } \\
\text { medication. }\end{array}$ \\
\hline 31 & I believe that it is faith in Islam that relieves my suffering from disease. \\
\hline 32 & I think that Islam is the main reason I do not believe in suicide. \\
\hline 33 & When the pain of the disease is overwhelming, there is nothing more powerful and effective than the prayer. \\
\hline 34 & I believe that faith positively affects both my mental and physical health. \\
\hline 35 & I can only get sick or worse with medication. \\
\hline 36 & I am worried when God does not respond to my call for healing. \\
\hline 37 & When I have to face a problem in my life, I think it is a penalty for a bad deed I have committed. \\
\hline 38 & I consider the teachings and precepts of Islam to be inspiring and guiding my daily behavior. \\
\hline 39 & I think the problems we are experiencing in this age are because of the distance from Islam. \\
\hline 40 & I believe that Islam is the path of salvation and eternal happiness. \\
\hline
\end{tabular}

beliefs, and practice subscales and overall scale yielded a coefficient of $-0.18(P=0.010),-0.19(P=0.007)$, and -0.21 $(P=0.003)$, respectively.

The results of the multivariate analysis indicated that religious beliefs and practices influenced the number of fasting days in a statistically significant way, after adjusting for confounders (beta standardized coefficient $=-0.199$, $t=-2.917, P=0.004)$. Another variable that impacted on the number of fasting days was the presence of complications (beta standardized coefficient $=-0.194, t=-2.775, P=0.006$ ). 
Table 3 Descriptive statistics of each item of the questionnaire

\begin{tabular}{|c|c|c|c|c|c|c|}
\hline \multirow[t]{2}{*}{ Item } & \multirow[t]{2}{*}{ Mean } & \multirow[t]{2}{*}{ SD } & \multicolumn{2}{|l|}{ Skewness } & \multicolumn{2}{|l|}{ Kurtosis } \\
\hline & & & Statistics & Standard error & Statistics & Standard error \\
\hline Item I & 2.408 & $1.40 \mathrm{I}$ & 0.510 & 0.172 & -1.159 & 0.341 \\
\hline Item 2 & 3.005 & 1.512 & 0.079 & 0.172 & -1.459 & 0.341 \\
\hline Item 3 & 3.189 & I.47I & -0.189 & 0.172 & -1.364 & 0.341 \\
\hline Item 4 & 2.960 & 1.236 & -0.052 & 0.172 & -0.902 & $0.34 I$ \\
\hline Item 5 & 3.323 & 1.323 & -0.287 & 0.172 & -1.035 & 0.341 \\
\hline Item 6 & 3.015 & 1.290 & -0.268 & 0.172 & -0.965 & $0.34 I$ \\
\hline Item 7 & 3.045 & 1.369 & -0.200 & 0.172 & -1.171 & $0.34 I$ \\
\hline Item 8 & 3.458 & 1.253 & -0.689 & 0.172 & -0.486 & 0.341 \\
\hline Item 9 & 3.229 & 1.333 & -0.427 & 0.172 & -0.962 & $0.34 I$ \\
\hline Item 10 & 2.940 & 1.160 & 0.098 & 0.172 & -0.739 & $0.34 I$ \\
\hline Item II & 2.756 & 1.275 & 0.072 & 0.172 & -1.085 & $0.34 I$ \\
\hline Item 12 & 2.761 & 1.205 & 0.020 & 0.172 & -0.896 & $0.34 I$ \\
\hline Item 13 & 3.020 & 1.277 & -0.096 & 0.172 & -1.058 & 0.341 \\
\hline Item 14 & 2.985 & 1.447 & -0.004 & 0.172 & -1.300 & 0.341 \\
\hline Item 15 & 3.110 & 1.431 & -0.029 & 0.172 & -1.387 & $0.34 I$ \\
\hline Item 16 & 2.990 & 1.490 & 0.036 & 0.172 & -1.401 & 0.341 \\
\hline Item 17 & 3.144 & 1.343 & -0.354 & 0.172 & -1.035 & $0.34 I$ \\
\hline Item 18 & 3.124 & 1.449 & -0.229 & 0.172 & -1.324 & $0.34 I$ \\
\hline Item 19 & 2.896 & 1.369 & -0.152 & 0.172 & -1.256 & 0.341 \\
\hline Item 20 & 2.960 & 1.438 & -0.133 & 0.172 & -1.411 & 0.341 \\
\hline Item 2I & 3.189 & 1.181 & -0.225 & 0.172 & -0.454 & 0.341 \\
\hline Item 22 & 3.547 & 1.034 & -0.128 & 0.172 & -0.480 & $0.34 I$ \\
\hline Item 23 & 3.587 & 0.956 & -0.408 & 0.172 & 0.237 & $0.34 I$ \\
\hline Item 24 & 3.821 & 0.817 & -0.380 & 0.172 & 0.012 & $0.34 I$ \\
\hline Item 25 & 3.995 & 0.935 & -0.731 & 0.172 & 0.377 & 0.341 \\
\hline Item 26 & 3.965 & 0.897 & -0.772 & 0.172 & 0.786 & $0.34 I$ \\
\hline Item 27 & 3.672 & 1.073 & -0.564 & 0.172 & -0.235 & 0.341 \\
\hline Item 28 & 3.725 & 1.169 & -0.669 & 0.172 & $-0.24 I$ & 0.342 \\
\hline Item 29 & 3.826 & 1.084 & -1.005 & 0.172 & 0.755 & $0.34 I$ \\
\hline Item 30 & 3.537 & 1.109 & -0.673 & 0.172 & 0.060 & $0.34 I$ \\
\hline Item 31 & 3.622 & 1.143 & -0.781 & 0.172 & 0.109 & $0.34 I$ \\
\hline Item 32 & 3.692 & 1.079 & -0.565 & 0.172 & -0.249 & $0.34 I$ \\
\hline Item 33 & 3.791 & 1.066 & -0.750 & 0.172 & 0.075 & $0.34 I$ \\
\hline Item 34 & 3.627 & 1.125 & -0.523 & 0.172 & -0.335 & $0.34 I$ \\
\hline Item 35 & 3.328 & 1.154 & -0.491 & 0.172 & -0.437 & $0.34 I$ \\
\hline Item 36 & 3.313 & I. 177 & -0.501 & 0.172 & -0.443 & $0.34 I$ \\
\hline Item 37 & 3.323 & 1.217 & -0.508 & 0.172 & -0.554 & $0.34 I$ \\
\hline Item 38 & 3.721 & 1.180 & -0.735 & 0.172 & -0.193 & $0.34 I$ \\
\hline Item 39 & 4.020 & 1.049 & -1.065 & 0.172 & 0.682 & 0.341 \\
\hline Item 40 & 4.110 & 1.085 & -1.286 & 0.172 & 1.112 & $0.34 I$ \\
\hline
\end{tabular}

For further details, see Table 5. The "negative" section of the Ramadan subscale predicted less fasting days (B nonstandardized coefficient $=-0.142$, standard error $=0.051$, beta standardized coefficient $=-0.188, t=-2.754, P=0.006$ ), whereas the "positive" section of the subscale did not impact on the number of fasting days $(P>0.05)$. Overall, the Ramadan subscale influenced the number of fasting days (B nonstandardized coefficient $=-0.104$, standard error $=0.039$, beta standardized coefficient $=-0.183, t=-2.685, P=0.008$ ). Interestingly, higher scores at the religious beliefs and practices predicted less fasting days (B nonstandardized coefficient $=-0.134$, standard error $=0.054$, beta standardized coefficient $=-0.172, t=-2.471, P=0.014)$.

\section{Discussion}

Ramadan represents a unique and extremely popular moment for Muslims worldwide. ${ }^{89}$ This study contributes to shedding light on the determinants of fasting even though being ill would guarantee the exemption from restraining oneself from food and beverages. 
Table 4 Reliability statistics for each item of the questionnaire

\begin{tabular}{|c|c|c|c|c|c|}
\hline Item & $\begin{array}{l}\text { Scale mean if } \\
\text { item deleted }\end{array}$ & $\begin{array}{l}\text { Scale variance } \\
\text { if item deleted }\end{array}$ & $\begin{array}{l}\text { Corrected item- } \\
\text { total correlation }\end{array}$ & $\begin{array}{l}\text { Squared multiple } \\
\text { correlation }\end{array}$ & $\begin{array}{l}\text { Cronbach's alpha } \\
\text { if item deleted }\end{array}$ \\
\hline Item I & 131.310 & 493.300 & 0.627 & 0.724 & 0.905 \\
\hline Item 2 & 130.720 & 487.147 & 0.670 & 0.803 & 0.904 \\
\hline Item 3 & 130.545 & 497.727 & 0.524 & 0.688 & 0.906 \\
\hline Item 4 & 130.770 & 506.238 & 0.476 & 0.595 & 0.907 \\
\hline Item 5 & 130.400 & 496.231 & 0.614 & 0.715 & 0.905 \\
\hline Item 6 & 130.720 & 512.806 & 0.340 & 0.663 & 0.909 \\
\hline Item 7 & 130.685 & 497.654 & 0.568 & 0.743 & 0.906 \\
\hline Item 8 & 130.265 & 507.824 & 0.439 & 0.689 & 0.908 \\
\hline Item 9 & 130.505 & 503.980 & 0.477 & 0.552 & 0.907 \\
\hline Item 10 & 130.790 & 529.182 & 0.070 & 0.594 & 0.912 \\
\hline Item II & 130.970 & 545.919 & -0.223 & 0.448 & 0.916 \\
\hline Item 12 & 130.960 & 523.164 & 0.175 & $0.48 I$ & 0.911 \\
\hline Item 13 & 130.695 & 505.650 & 0.472 & 0.529 & 0.907 \\
\hline Item 14 & 130.740 & 498.274 & 0.523 & 0.633 & 0.906 \\
\hline Item 15 & 130.620 & 490.116 & 0.663 & 0.780 & 0.904 \\
\hline Item 16 & 130.730 & $488.68 I$ & 0.657 & 0.702 & 0.904 \\
\hline Item 17 & 130.580 & 496.948 & 0.591 & 0.695 & 0.906 \\
\hline Item 18 & 130.605 & 497.306 & 0.538 & 0.590 & 0.906 \\
\hline Item 19 & 130.825 & 499.030 & 0.545 & 0.672 & 0.906 \\
\hline Item 20 & 130.770 & 505.957 & 0.405 & 0.545 & 0.908 \\
\hline Item 2I & 130.535 & 498.642 & 0.647 & 0.766 & 0.905 \\
\hline Item 22 & 130.180 & 511.877 & 0.455 & 0.624 & 0.908 \\
\hline Item 23 & 130.135 & 513.303 & 0.462 & 0.673 & 0.908 \\
\hline Item 24 & 129.900 & 517.668 & 0.428 & 0.529 & 0.908 \\
\hline Item 25 & 129.735 & 511.040 & 0.529 & 0.600 & 0.907 \\
\hline Item 26 & 129.755 & 514.387 & 0.469 & 0.632 & 0.908 \\
\hline Item 27 & 130.055 & 512.314 & 0.427 & 0.677 & 0.908 \\
\hline Item 28 & 130.000 & 510.221 & 0.429 & 0.646 & 0.908 \\
\hline Item 29 & 129.895 & 518.265 & 0.300 & 0.480 & 0.909 \\
\hline Item 30 & 130.190 & 514.054 & 0.376 & 0.533 & 0.908 \\
\hline Item 3I & 130.100 & 515.849 & 0.329 & 0.533 & 0.909 \\
\hline Item 32 & 130.035 & 516.305 & 0.342 & 0.569 & 0.909 \\
\hline Item 33 & 129.935 & 514.322 & 0.388 & 0.547 & 0.908 \\
\hline Item 34 & 130.105 & 515.089 & 0.351 & 0.395 & 0.909 \\
\hline Item 35 & 130.395 & 519.486 & 0.255 & 0.484 & 0.910 \\
\hline Item 36 & 130.415 & 525.128 & 0.143 & 0.563 & 0.911 \\
\hline Item 37 & 130.390 & 517.124 & 0.285 & 0.488 & 0.910 \\
\hline Item 38 & 130.010 & 511.105 & 0.408 & 0.626 & 0.908 \\
\hline Item 39 & 129.695 & 512.022 & 0.449 & 0.591 & 0.908 \\
\hline Item 40 & 129.610 & 510.862 & 0.453 & 0.472 & 0.908 \\
\hline
\end{tabular}

Table 5 Multivariate regression analysis

\begin{tabular}{|c|c|c|c|c|c|}
\hline \multirow[t]{2}{*}{ Parameter } & \multicolumn{2}{|c|}{ Nonstandardized coefficients } & \multirow{2}{*}{$\begin{array}{l}\begin{array}{l}\text { Standardized } \\
\text { coefficients }\end{array} \\
\text { Beta } \\
\text { coefficient }\end{array}$} & \multirow[t]{2}{*}{$\mathbf{T}$} & \multirow[t]{2}{*}{ Sig. } \\
\hline & $\begin{array}{l}\text { B } \\
\text { coefficient }\end{array}$ & SD & & & \\
\hline Constant & 38.141 & 4.303 & & 8.865 & 0.000 \\
\hline Gender & 1.319 & 1.183 & 0.076 & 1.115 & 0.266 \\
\hline Age & -0.077 & 0.046 & -0.142 & -1.658 & 0.099 \\
\hline Family status & 1.928 & 1.494 & 0.105 & 1.290 & 0.198 \\
\hline Educational level & 1.049 & 1.646 & 0.045 & 0.637 & 0.525 \\
\hline Occupation & 1.116 & 1.324 & 0.060 & 0.843 & 0.400 \\
\hline Diabetic complications and comorbidities & -3.505 & 1.263 & -0.194 & -2.775 & 0.006 \\
\hline Fasting and religious beliefs and practices & -0.074 & 0.025 & -0.199 & -2.917 & 0.00 \\
\hline
\end{tabular}


Muslim diabetics have particular healthcare needs. Diabetes is perceived by interviewees through a religious lens as predestined.${ }^{10}$ Western drugs represent only a small fraction of the world, in which it is the faith to play a major role. ${ }^{11-14}$ Ramadan should be conceived as a collective ritual, a rite of passage, a transition from adolescence to adulthood, the entrance of the individual into the societal and groupal organization, which is deeply rooted within the Arab-Muslim society. ${ }^{10}$ This society attributes great importance to values, such as cohesion. Islam is characterized by different pillars, including the declaration of faith, prayers five times a day, the pilgrimage to Makkah, charity or alms-giving, and the fasting. However, the latter differs significantly from the former ones, in that exposes the Muslim to the sight and presence of other people, and, as such, to their judgments, mockery, and criticisms. ${ }^{15}$ Therefore, fasting may be lived with a sense of social obligation or cultural constraint rather than as a religious duty: it is undeniable that Ramadan is a major event that contributes to the construction of the self and to the articulation of one's own identity.

In the sample we interviewed, the feelings of guilt, shame, and social pressure were strongly perceived and common: $60.7 \%$ of the subjects expressed such intense sensations (item 16, "I would feel guilty if I would follow the "shuyukh, fuqahā, a'immah" (spiritual guides/leaders)'s advice, who have permitted me not to fast").

Intriguingly, a negative relation was found between religious knowledge and observance of fasting: according to the official Islam, a diabetic is, indeed, exempted from fasting and receives benefit if not fasting. According to traditional, low-level magic-religious beliefs, ${ }^{17}$ instead, a disorder is interpreted as a divine punition for a sin and fasting represents the best solution for being forgiven by God. Ramadan fasting is not only a duty or an obligation, but it represents a strongly and deeply rooted sociocultural value.

Considering items 27,28,30, and 35, it is noteworthy that a percentage of population ranging from $49.2 \%$ to $59.7 \%$ was skeptical about the role of Western medicine and thinks that taking drugs cannot impact on one's own health and, in some cases, can even worsen the health status and/or leading to the disease state. Interestingly, at the univariate chi-squared test, there was no impact of educational level except for item 30 ( $P$-values of $0.224,0.396,0.001$, and 0.540 for items 27, 28, 30 , and 35 , respectively).

These findings emphasize the importance of providing a proper, effective education for both diabetic patients and medical staff, which needs to receive a culturally sensitive training. ${ }^{16}$
Few studies are available for a comparison: these include the investigation carried out by Ababou et al, ${ }^{17}$ which have assessed, in a sample of 212 women and 95 men from Casablanca and Fes (Morocco), the intergenerational transmission of religious values and practices, including the fasting during the month of Ramadan, in terms of age group, gender, and generation. Overall, $64 \%$ of the patients had fasted for the entire month, whereas $22 \%$ of the sample did not fast and $15 \%$ fasted partially. Educational level, as well as the marital status, did not show an impact on the decision of fasting, similar to our findings.

Despite its novelty, our study suffers from a number of shortcomings that should be properly recognized. The major limitation is given by the study design (cross-sectional nature) of the investigation, as well as the lack of detailed information concerning the treatment received at baseline and how it was modified during and after the month of Ramadan. Moreover, given the exploratory nature of the study, we used a convenience sample. Further studies should replicate our findings using a longitudinal design and, eventually, also controls (that is to say, diabetics not willing to fast, in order to explore differences between the groups).

\section{Conclusion}

The large proportion of both type 1 and type 2 diabetic subjects who wish to fast during Ramadan represent a major challenge for the physicians. Our questionnaire investigating Ramadan fasting beliefs as well as other religious creeds and practices in type 2 diabetics proved to be a valid and reliable instrument that can be used to shed light on the determinants of deciding whether to fast during the month of Ramadan. However, due to the above-mentioned shortcomings, further research in the field is needed.

\section{Disclosure}

The authors report no conflicts of interest in this work.

\section{References}

1. Bhutani J, Bhutani S. Worldwide burden of diabetes. Indian J Endocrinol Metab. 2014;18(6):868-870.

2. van Dieren S, Beulens JW, van der Schouw YT, Grobbee DE, Neal B. The global burden of diabetes and its complications: an emerging pandemic. Eur J Cardiovasc Prev Rehabil. 2010;17(Suppl 1):S3-S8.

3. Spanakis EK, Golden SH. Race/ethnic difference in diabetes and diabetic complications. Curr Diab Rep. 2013;13(6):814-823.

4. Abuyassin B, Laher I. Diabetes epidemic sweeping the Arab world. World J Diabetes. 2016;7(8):165-174.

5. Salti I, Bénard E, Detournay B, et al. A population-based study of diabetes and its characteristics during the fasting month of Ramadan in 13 countries: results of the epidemiology of diabetes and Ramadan 1422/2001 (EPIDIAR) study. Diabetes Care. 2004;27(10):2306-2311. 
6. Jabbar A, Hassanein M, Beshyah SA, Boye KS, Yu M, Babineaux SM. CREED study: hypoglycaemia during Ramadan in individuals with Type 2 diabetes mellitus from three continents. Diabetes Res Clin Pract. 2017;132:19-26.

7. Hinkle DE, Wiersma W, Jurs SG. Applied Statistics for the Behavioral Sciences. 5th ed. Boston: Houghton Mifflin; 2003.

8. Bragazzi NL. Ramadan fasting and chronic kidney disease: a systematic review. J Res Med Sci. 2014;19(7):665-676.

9. Bragazzi NL, Briki W, Khabbache H, et al. Ramadan fasting and infectious diseases: a systematic review. J Infect Dev Ctries. 2015;9(11): 1186-1194.

10. Patel NR, Kennedy A, Blickem C, Rogers A, Reeves D, Chew-Graham C. Having diabetes and having to fast: a qualitative study of British Muslims with diabetes. Health Expect. 2015;18(5):1698-1708.

11. Sunni M, Brunzell C, Nathan B, Moran A. Management of diabetes during Ramadan: practical guidelines. Minn Med. 2014;97(6):36-38.
12. Almalki MH, Hussen I, Khan SA, Almaghamsi A, Alshahrani F. Assessment of Ramadan education and knowledge among diabetic patients. Clin Med Insights Endocrinol Diabetes. 2018;11:117955141775161.

13. Zainudin SB, Hussain AB. The current state of knowledge, perception and practice in diabetes management during fasting in Ramadan by healthcare professionals. Diabetes Metab Syndr. 2018;12(3):337-342.

14. Ang DY, Soh AW. Knowledge of diabetes mellitus and safe practices during Ramadan fasting among Muslim patients with diabetes mellitus in Singapore. Singapore Med J. 2017;58(5):246-252.

15. YahyaouiA. Rites en l'islaml'adolescence. Adolescence. 2010;28(3):617-623.

16. Ahmedani MY, Ahsan S, Haque MSU. Role of Ramadan specific diabetes education (RSDE): a prospective study. Pak J Med Sci. 2017;33(3):586-593.

17. Ababou M, Ababou R, El Maliki A. Ramadan fasting: dilemma for diabetic patients and physicians in Morocco. Sciences sociales et santé. 2008;26(2):79-104.
Diabetes, Metabolic Syndrome and Obesity: Targets and Therapy is an international, peer-reviewed open-access journal committed to the rapid publication of the latest laboratory and clinical findings in the fields of diabetes, metabolic syndrome and obesity research. Original research, review, case reports, hypothesis formation, expert opinion and commentaries are all considered for publication. The manuscript management system is completely online and includes a very quick and fair peer-review system, which is all easy to use. Visit http://www.dovepress.com/testimonials.php to read real quotes from published authors. 